\title{
Feature review Ken Saro-Wiwa: Assessing the multiple legacies of a literary interventionist
}

\section{Scott Pegg}

To cite this article: Scott Pegg (2000) Feature review Ken Saro-Wiwa: Assessing the multiple legacies of a literary interventionist, Third World Quarterly, 21:4, 701-708, DOI: 10.1080/713701071

To link to this article: https://doi.org/10.1080/713701071

$$
\text { Published online: } 25 \text { Aug } 2010 .
$$

Submit your article to this journal 4

Џلll Article views: 121

Citing articles: 4 View citing articles 4 


\title{
FEATURE REVIEW
}

\section{Ken Saro-Wiwa: assessing the multiple legacies of a literary interventionist}

Scott Pegg

Ogoni's Agonies: Ken Saro-Wiwa and the Crisis in Nigeria

Abdul Rasheed Na'Allah (ed)

Trenton, NJ: Africa World Press, 1998

pp 388

Before I Am Hanged: Ken Saro-Wiwa, Literature, Politics and Dissent

Onookome Okome (ed)

Trenton, NJ: Africa World Press, 2000

pp 224

Ken Saro-Wiwa: Writer and Political Activist

Craig W McLuckie \& Aubrey McPhail (eds)

Boulder, CO: Lynne Rienner, 2000

pp 291

\author{
Ken Saro-Wiwa: A Bio-critical Study \\ Femi Ojo-Ade \\ New York: Africana Legacy Press, 1999 \\ pp 300
}

Among his countrymen Ken Saro-Wiwa was best known as the writer, producer and director of the hit television series Basi and Company which ran from 1985 to 1990 and attracted an estimated 30 million viewers per week-making it arguably the most successful local television show ever produced in Africa. Beyond a select group of African literary scholars and committed environmental and human rights activists, however, Saro-Wiwa was largely unknown outside Nigeria until 1993, when the Movement for the Survival of the Ogoni People (MOSOP) staged the largest peaceful demonstrations ever held against a transnational oil company. On 4 January 1993 some 300000 Ogoni (out of a total population of 500 000) protested against the environmental devastation of their homeland and demanded a greater share of oil revenues. The subsequent government crackdown on the Ogoni population left more than 2000 civilians dead and tens of thousands homeless. It also led to a sham trial against a number of MOSOP leaders that concluded on 10 November 1995 with the hangings of Saro-Wiwa and eight other Ogonis in a process that former British prime minister John Major aptly termed 'judicial murder'.

The four books under review here represent the first generation of scholarship to 
evaluate Saro-Wiwa's life, legacy and martyrdom. While various authors in these volumes address the complexities of Saro-Wiwa's life as a whole, all four books follow a similar format of compartmentalising his work into discrete pieces that can then be analysed separately_poetry, short stories, novels, journalism, activism, and the like. Of the four of them, McLuckie and McPhail, despite a few weak chapters, is clearly the strongest and most consistent overall volume. While Misty L Bastian's voyeuristic tourist look at a demonstration in commemoration of the executed Ogoni leaders is overblown and melodramatic, most of the chapters in this volume are quality pieces of scholarship. This volume is also the most comprehensive of the four in addressing the various aspects of Saro-Wiwa's literary, business and political career.

The other three works all contain outstanding chapters but suffer horribly from poor editing. The Na'Allah and Okome volumes are extremely repetitive and the Na'Allah volume's 47 poems could benefit from pruning. Both of these edited volumes are also debilitated by chapters that vary tremendously in quality. Sophisticated, innovative and insightful analyses (for example, Breitinger \& Schulze-Engler in Na'Allah, Ileoje \& Telilanyo in Okome) often sit next to facile and tepid chapters which demonstrate shoddy scholarship.

Femi Ojo-Ade's single author work follows the same format as the three edited volumes, with more or less stand-alone chapters on Saro-Wiwa's poetry, short stories, journalism and the like. It thus suffers from a lack of diversity in contributors that is not compensated for by any strong and coherent central thesis running through the text. Ojo-Ade undermines his own work with poor argumentation, repeated assertions unsupported by evidence, factual errors (such as referring to Shell-BP in the present tense when BP was nationalised in 1979) and so many spelling mistakes that one wonders if this book was proofread.

Both the Na'Allah and the McLuckie and McPhail volumes contain extensive bibliographies of works by and about Ken Saro-Wiwa, as well as of other relevant works. Though extensive, the Na'Allah bibliography is disorganised and weakened by a number of serious omissions, including no internet resources and no information on the various NGO reports issued on the Ogoni crisis. The annotated bibliography compiled by Craig W McLuckie and James Gibbs addresses some of these problems and is both more comprehensive and better organised than Na'Allah's. Even here, though, one finds major omissions in terms of NGO reports, ${ }^{1}$ internet resources ${ }^{2}$ and other works. ${ }^{3}$

None of these four volumes can be considered definitive and three of them suffer from serious flaws. Taken collectively, however, if one seeks out the proverbial diamonds in the rough, the four volumes provide a number of fascinating insights into Ken Saro-Wiwa's life and work, some of which are highlighted below.

\section{A short man with tall parts}

In response to a critic who once hypothesised that the genesis of the views that offended him resided in Saro-Wiwa's short physical stature, the author sardonically replied that 'Unfortunately, he is ignorant of my tall parts'. ${ }^{4}$ Although each of these four books tends to disaggregate the various components of Saro-Wiwa's life, one of the striking things to emerge from them is just how coherently linked the different parts of the Ken Saro-Wiwa whole were. In terms of his writing, Ojo-Ade highlights the fact that 'his fiction is inescapably realistic ... addressing current socio-political and economic issues'. Conversely, 'a striking aspect of Saro-Wiwa's non-fictional work ... is their artistry; the satirist, the dramatist, the poet, each is ever present ...' ( $p$ xvii). Similarly, Imo Ben Eshiet (in Okome) notes that, while politics is a constant in all of Saro-Wiwa's works, it is 'assimilated into his aesthetic unobtrusively, obliquely, naturally'. His fictional 
works are thus 'aesthetically pleasing presentations of the ugly' (p 49). Yet, as Frank Schulze-Engler (in Na'Allah) argues, 'the popular, often humorous vein in which this satirical vision was put across ... did not diminish the radical anger that informs most of Saro-Wiwa's writing' (p 286).

Perhaps the most fascinating nexus linking Saro-Wiwa's fictional writing and his political activism together is his business acumen. Saro-Wiwa's business and publishing efforts are ably engaged by both Laura Neame (in McLuckie \& McPhail) and Eckhard Breitinger (in Na'Allah). Breitinger's insightful contribution describes Saro-Wiwa as a 'cultural entrepreneur' ( $p$ 247) whose concepts extended far beyond what could be done in the print media alone. This forced him to self-publish and to devise his own multimedia structures of delivery and distribution. Operating in the challenging business environment of post-oil bust Nigeria, Saro-Wiwa maintained control over all aspects of his cultural productions - handling everything other than the actual printing and binding of his books and literally controlling every single aspect of Basi and Company from writing, producing, directing and editing the show to financing, marketing and distributing it.

Saro-Wiwa also creatively recycled his own output and carefully addressed a variety of target markets. His belief in the power of ideas led him to self-publish at a loss. As his eldest son Ken Wiwa explained to Laura Neame (in McLuckie \& McPhail) 'he published books at a loss not because, as they've tried to say, because he was vain, but simply because he wanted the germ of the ideas to remain forever' ( $p$ 156). Two of his journalistic efforts were recycled into books (Prisoners of Jebs and Similia: Essays on Anomic Nigeria) to ensure their ideas a greater permanency. The television show Basi and Company was also spun off into a plethora of different books variously targeting young children, secondary school students and adults. Neame (in McLuckie \& McPhail) concludes that 'as a means of increasing reading and literacy levels within Nigeria, his

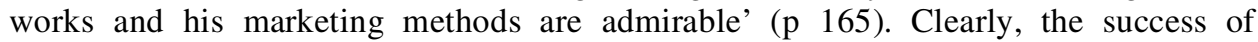
Saro-Wiwa the writer and political activist was inextricably interwoven with and dependent upon the success of Saro-Wiwa the businessman. Breitinger (in Na'Allah) reminds us that any evaluation of Ken Saro-Wiwa's phenomenal impact must address 'not only the ideas, not only the word', but also his 'extraordinary efficiency and capability in making the word go round.' (p 252).

\section{Literature in the streets}

In his efforts to make words go round, Ken Saro-Wiwa was guided by a fundamental philosophy of the role and responsibility of the writer in confronting injustice. Specifically, Saro-Wiwa believed that 'literature in a critical situation such as Nigeria's cannot be divorced from politics. Indeed, literature must serve society by steeping itself in politics, by intervention, and writers must not write merely to amuse ... They must play an interventionist role'. ${ }^{5}$ Saro-Wiwa was by no means dogmatic here. Indeed, he freely acknowledged that 'I've often envied those writers in the Western world who can peacefully practice their craft and earn a living thereby. I cannot say that I would not have preferred that to the dangerous paths through which my art is taking me'. ${ }^{6}$ His literary interventionism was determined by his status as a member of a poor and marginalised minority oil-producing community. As he put it in an interview excerpted in Na' Allah, 'writers are led into different things ... You react to your situation. If I were Yoruba maybe I would not be an activist.' For a member of a community that produced billions of dollars of oil wealth but whose members themselves lack electricity and clean drinking water, however, 'you must go into activism because if you're not into activism, then you're irresponsible' (p 341). 
Activist writers across the world, however, often suffer from audiences that comprise only a relatively tiny group of educated elites. Something that so distinguished Ken Saro-Wiwa here was his belief that the writer 'must take part in mass organizations' and 'establish direct contact with the people'. ${ }^{7}$ The goal was to take literature to the streets. In a letter smuggled out of his prison cell a few months before he was executed, Saro-Wiwa noted that 'the goons in authority here do give us freedom to write, knowing full well that only a few people read, anyway. What they cannot stand is that a writer should additionally give voice to the voiceless and organize them for action. In short, they do not want literature on the streets! And that is where, in Africa, it must be. ${ }^{8}$ Ken Saro-Wiwa was hanged because he was the only Nigerian and arguably the only writer in the world capable of bringing tens of thousands of people out in the streets.

Saro-Wiwa's extraordinary dedication and commitment here is also striking. At various points in his career he worked for the Nigerian government and accepted government contracts. Once he dedicated himself completely to the Ogoni cause in the 1990s, though, Saro-Wiwa refused to be bought off or, in Nigerian terms, 'settled'. Ojo-Ade describes Saro-Wiwa's first detention in 1993 as 'a kind of warning, like the Mafia giving their quarry a thorough beating and a broken nose, so that he may desist from actions deserving of death' (pp xix-xx). Fully aware of the dangers ahead of him, Saro-Wiwa persisted with his cause and turned down numerous financially attractive offers to go into exile or simply shut up. He chose not to parlay his activist success into private personal gain but to devote 'my intellectual and material resources, my very life, to a cause in which I have total belief and from which I cannot be blackmailed or intimidated'. ${ }^{9}$ Nigeria's Nobel laureate Wole Soyinka once argued that 'the man dies in all who keep silent in the face of tyranny'. ${ }^{10}$ On that basis, Ken Saro-Wiwa surely lived at least 10000 lives.

\section{Sarcasm's arrow}

Ken Saro-Wiwa could be scathing in his criticism of elites and traditional elders. For someone so concerned with bringing literature to the streets, though, it is not surprising that Saro-Wiwa directed much of his sarcastic commentary not at elites but at society as a whole. In both Sozaboy: A Novel in Rotten English and the first half of his short story collection, A Forest of Flowers, Saro-Wiwa uses the fictionalised town of Dukana as his could-be-anywhere rural Ogoni village setting. One does not find idyllic visions of rural harmony here besmirched only by the noxious interventions of the transnational oil companies. On the contrary, as Schulze-Engler (in Na'Allah) points out, Saro-Wiwa's writing is characterised 'by a stern refusal to fall in line with populist myths of the "good people" as a resource of wisdom and good will' (p 291). McPhail (in McLuckie \& McPhail) describes Saro-Wiwa's Dukana as 'a place of squalor, ignorance, superstition, fear, and intolerance' (p 70). The novel Sozaboy ends with the narrator-hero Mene being exiled from Dukana after the Biafran war because the villagers think he is a ghost. A number of the stories in A Forest of Flowers reach similarly unhappy conclusions because of the monstrous stupidity, fanaticism and cruel stagnation so characteristic of 'tradition' in Saro-Wiwa's work. In 'Home, Sweet Home', a woman is exiled from the village for having twins. A man who goes mad is buried alive by his own family in 'A Family Affair' and an industrious but individualistic farmer is burned to death in 'The Bonfire'. Although unsparing in his criticism of fellow elites, Saro-Wiwa's literature clearly indicates that they are far from the only problem facing Nigeria.

Literature and politics are again conjoined here. The television series Basi and Company, for example, targeted not just corrupt individuals but rather Nigeria's 'culture of cheating' as a whole. As far back as 1966 Chris Dunton (in McLuckie \& McPhail) 
finds Saro-Wiwa addressing the theme of collaborators and those who complacently go along with unjust rule in his play 'Dreams of Sologa' - a theme that would again show up in his closing statement to the military-appointed tribunal that sentenced him to death in 1995. Having recently made a transition from military to civilian rule, Nigerians would be well advised to heed Schulze-Engler's conclusion (in Na'Allah) that 'the legacy of Saro-Wiwa's satirical writings lies in the insight that the movement towards democratic transition will have to address the basic social illnesses of Nigeria, of which its military rulers are symptoms rather than prime causes' (p 302).

\section{Criticisms and hallucinations}

An opinionated, forthright and forceful person, Ken Saro-Wiwa generated controversy and attracted criticism throughout his life. None of the books under review here buys into the Saro-Wiwa as saint myth and all engage his work critically. Some critiques address Saro-Wiwa's aesthetic but the more interesting ones focus on his political ideas. Femi Ojo-Ade, for example, lambasts Saro-Wiwa for continually focusing on the theme of the three majority groups (the Hausa-Fulani, Igbo and Yoruba), collectively marginalising the minorities and thus neglecting the fundamental importance of Nigeria's north-south divide, which also subordinates the Igbo and Yoruba under the yoke of northern hegemony ( $\mathrm{p}$ 214). Although not going so far as to hold him responsible for creating the climate which led to the murders of four pro-government Ogoni chiefs on 21 May 1994 (the ostensible charge for which Saro-Wiwa was hanged), Ato Quayson (in Na'Allah) argues that Saro-Wiwa's tragic flaw 'was in misapprehending the extent to which his followers had been subjectivized by the thuggery and violence already delimited by the ethos of Nigerian politics and in not addressing this systematically from the very beginning of the struggle' ( $p$ 76). Quayson might be correct in the sense that it was beyond the means of one individual to overcome fully the violence that comprises the very fabric of Nigerian politics, but Saro-Wiwa's commitment to non-violence was clearly and consistently expressed from the very beginning of the struggle.

Without question, the area where Saro-Wiwa comes in for the most sustained criticism concerns his memoir On a Darkling Plain: An Account of the Nigerian Civil War. Azubike Ileoje (in Okome) and Ojo-Ade both criticise Saro-Wiwa for failing to understand the Igbos' legitimate fear of genocide. Ileoje's sophisticated and insightful critique argues that Saro-Wiwa singularly fails to provide any evidence of pre-1967 abuse of political power by the Igbo to the detriment of the Ogoni and that his work is merely 'an insistent expression of awe at the sheer number of the Igbo' ( $p$ 112). Related to this, he lambasts Saro-Wiwa for not coming to grips with 'that aspect of democracy which would allocate and/or allow power commensurate with the numerical strength of constituent groups' (p 120). McLuckie (in McLuckie \& McPhail) concludes that On a Darkling Plain is a 'badly rendered, biased, and in areas a repugnant memoir ...' (p 45).

Much of the criticism here hinges on the question of whether or not Ken Saro-Wiwa's human vision suffered from narrow ethnocentrism. Ojo-Ade, for example, accuses Saro-Wiwa of 'Igbophobia' ( $\mathrm{p}$ 13), while Okome (in Okome) criticizes him for not making 'any attempt to bring all the devastated and marginalized people of the Niger Delta into the forefront of this struggle' ( $\mathrm{p} x \mathrm{xi}$ ). Saro-Wiwa's views of the Igbo are problematic and, in places, offensive and deservedly condemned. The larger charge of narrow and virulent Ogoni ethnocentrism to the neglect of other oppressed peoples is, however, unsustainable. Saro-Wiwa's desire for Ogoni self-determination and political autonomy was not conceived in isolation. His vision of Nigeria as a confederation of equal and autonomous ethnic groups encompassed all Nigerians, not just the Ogoni. Indeed, he maintained that the 'Ogoni agenda,' which 'postulates the equality of all 
ethnic groups, big or small, within the Nigerian federation as well as the evolution of proper, undiluted federalism,' is 'the only one that can save Nigeria from future destruction'. ${ }^{11}$ The Ogoni struggle, with its emphasis on a charter document (the Ogoni Bill of Rights) setting out non-secessionist demands for political autonomy and greater control over natural resources can also be seen as a template for other oppressed minority groups to follow. ${ }^{12}$ Indeed, the recent proliferation of such documents as the Ijaws' Kaiama Declaration, the Ikwerre Rescue Charter and the Oron Bill of Rights demonstrates the continued relevance of the Ogoni model for other marginalised Niger Delta peoples. His views on the Igbo notwithstanding, Saro-Wiwa was not a tribal chauvinist.

Whether one agrees with them or not, the vast majority of critiques offered in these four volumes are legitimate, serious and worthy of engagement. The one glaring exception to this is Desmond Orage's contribution in the Na'Allah volume. Orage, the son and nephew of two of the four Ogoni chiefs murdered on 21 May 1994, obviously hates Ken Saro-Wiwa and holds him directly responsible for the violent deaths of his father and uncle. In expressing this hatred, Orage unleashes a stream of unsubstantiated venom and malicious invective that has no place whatsoever in a scholarly collection. His poorly written and repetitive character assassination is a collection of ridiculous and baseless allegations supported neither by arguments nor evidence. Perhaps his most ludicrous assertion is that Ken Saro-Wiwa's first action on becoming MOSOP's president was to declare war on three neighbouring tribes ( $\mathrm{p} 47$ ). Here Orage is referring to the 1993-94 so-called 'ethnic violence' between the Ogoni and, respectively, the Andoni, the Okrika and the Ndoki. Yet, Human Rights Watch concludes that 'some attacks attributed to rural minority communities were in fact carried out by army troops in plainclothes'. ${ }^{13}$ Looking specifically at the Andoni case, a World Council of Churches report similarly notes that 'the sophisticated weapons used in the attack were clearly beyond the means of a fishing community, pointing to some sort of military involvement in the attack'. ${ }^{14}$ Hundreds of Ogonis were brutally murdered in these so-called ethnic clashes. To attribute these government-initiated massacres to Saro-Wiwa declaring war on his neighbours is outrageous and beyond cynical. For Na'Allah to include such vicious and unsubstantiated rantings in his book demonstrates an abdication of editorial responsibility.

\section{Conclusions}

The four books reviewed here represent the first generation of scholarship on Ken Saro-Wiwa. The fascinating nature of the subject matter and the sometimes severe limitations illustrated in these works highlight a number of exciting prospects for future research. Most obviously, the world still awaits a comprehensive biography of Ken Saro-Wiwa. Ojo-Ade's 'bio-critical study' does not do the job and the mere four pages of 'bio-biography' in the Na'Allah volume and the three page 'chronology' of his life in the McLuckie and McPhail volume only highlight the need for a definitive biography.

These four works also reveal the desperate need for a Ken Saro-Wiwa reader or anthology. With the valuable but limited exceptions of Sozaboy, A Forest of Flowers and A Month and a Day: A Detention Diary, the vast majority of Ken Saro-Wiwa's works suffer from severely limited accessibility. Reading Dunton (in McLuckie \& McPhail) on Saro-Wiwa's unpublished plays, or the two interviews with him reproduced in Na'Allah, illustrates some of the potential material that could be offered in a Ken Saro-Wiwa reader. One can only imagine how many letters, manuscripts and interviews exist somewhere but are not readily available. Combining them with excepts from some of the published but out of print works like Genocide in Nigeria, On a Darkling Plain, and 
Songs in a Time of War would indeed produce a bountiful harvest for future scholars to reap.

In their annotated bibliography, McLuckie \& Gibbs (in McLuckie \& McPhail) maintain that 'a review of the available material shows a lack of sustained engagement with Saro-Wiwa's aesthetic and, not surprisingly, an overengagement with the political' ( $\mathrm{p}$ 245). Perhaps this is true if one counts all the newspaper accounts of the Ogoni struggle during the final years of Saro-Wiwa's life. On the basis of these four volumes, however, one would have to conclude exactly the opposite: there has been an overengagement with Saro-Wiwa's aesthetic and a lack of engagement with his politics. At least $70 \%$ of the contributors to these volumes (47 contributors out of a total of 67) are poets, writers and/or professors of English, modern languages, theatre or comparative literature. With a few notable exceptions, such as Schulze-Engler (in Na'Allah) and Nixon (in McLuckie \& McPhail), many of these contributors are simply out of their depth in analysing political matters. Recent scholarship of the sort that has addressed Niger Delta issues from the perspectives of business strategy, ${ }^{15}$ corporate responsibility ${ }^{16}$ and security studies $^{17}$ is woefully underrepresented in these volumes. The next generation of scholarship on Saro-Wiwa and the Niger Delta must be far more interdisciplinary and include contributions from economists, geographers, historians, political scientists and business scholars.

Finally, it is now nearly five years since Saro-Wiwa was hanged. None of these volumes does a good job of addressing subsequent developments within MOSOP or the Niger Delta as a whole. The divisive and public factional squabbling within MOSOP, though not unknown in Saro-Wiwa's day, seems to have reached new heights in the past year. Despite Nigeria's tentative return to democratic elections last year, little has changed in the Niger Delta in terms of environmental degradation, abject poverty, political marginalisation or the federal resources and land-use legislation that ensure things will remain that way. What has changed, however, is that the Ogoni are no longer a small minority struggling alone. Increasingly, their lead is being followed by dozens of other minorities, including the numerically much stronger Ijaw population. The increase in hostage-taking, the continued corporate-supported violent repression of peaceful protests and the indiscriminate military violence following the proclamation of the Kaiama Declaration in December 1998 all make Ken Saro-Wiwa's closing statement to the military-appointed tribunal look increasingly prophetic: 'I predict that the denouement of the riddle of the Niger Delta will soon come. The agenda is being set at this trial. Whether the peaceful ways I have favored will prevail depends on what the oppressor decides, what signals it sends out to the waiting public.'

\section{Epilogue}

A few weeks after submitting the above feature review to Third World Quarterly, I traveled to Ogoni to participate in a series of events culminating in a funeral and memorial service for Ken Saro-Wiwa on 24 April 2000. For a time it appeared as if the memorial service itself might not take place thanks to disputes among the families of the nine Ogonis hanged on 10 November 1995, and to factional divisions within MOSOP over how such an event should be conducted. In the end, however, the entire week of activities passed off successfully in a peaceful and festive manner. Saro-Wiwa the cultural preservationist, who compiled an anthology of some of his people's oral folk tales in The Singing Anthill, was honoured with a number of cultural presentations in his honour. Saro-Wiwa the environmentalist, who argued that a clean environment is humanity's first right, was honoured with a tree-planting ceremony on Earth Day 2000. Perhaps the greatest honour, though, for the writer who participated in mass organisa- 
tions and succeeded so well in establishing 'direct contact with the people', would have been the sight of thousands of ordinary Ogoni peasants walking dozens of kilometres to get to his home village of Bane to pay their respects. It is difficult to say with any certainty, as people were coming and going all day long, but my own estimate is that at least 15000 people and possibly as many as 25000 people attended the memorial service. Oronto Douglas, an Ijaw activist from the group Environmental Rights Action, told me that he thought it was the second biggest funeral in Nigerian history after that of the late musician and political activist Fela Kuti in 1997. Fela, however, lived in Lagos, which has a population base about 20 times larger than that of Ogoni. The man of ideas is gone, but the ideas themselves clearly remain vibrant.

\section{Notes}

The author thanks Barika Idamkue and Dr Owens Wiwa for their input.

${ }^{1}$ These include R Boele, Ogoni; Report of the UNPO Mission to Investigate the Situation of the Ogoni of Nigeria, The Hague: Unrepresented Nations and Peoples Organization, 1995; B Manby, The Price of Oil: Corporate Responsibility and Human Rights Violations in Nigeria's Oil Producing Communities, New York: Human Rights Watch, 1999; and D Robinson, Ogoni: The Struggle Continues, Geneva: World Council of Churches, 1996.

2 These include www.mosopcanada.org, the MOSOP website run by Saro-Wiwa's younger brother Owens Wiwa; www.shellnigeria.com, which, among other things, includes the now (in)famous 'Clear Thinking in Troubled Times' advertisement Shell placed one week after Saro-Wiwa's hanging; and the Shell-NigeriaAction listserve http://lists.essential.org/mailman/listinfo/shell-nigeria-action.

3 These include Saro-Wiwa's unpublished self-epitaph 'On the death of Ken Saro-Wiwa' which was excerpted as 'Ken Saro-Wiwa's last laugh' in Harper's Magazine, September 1996, pp 20-22 and the video Ken Saro-Wiwa: In Remembrance.

${ }^{4}$ K Saro-Wiwa, Similia: Essays on Anomic Nigeria, Port Harcourt: Saros International, 1991, p 159.

${ }^{5}$ K Saro-Wiwa, A Month and a Day: A Detention Diary, London: Penguin, 1995, p 81.

${ }^{6}$ K Saro-Wiwa, letter to William Benson, 17 July 1995.

${ }^{7} \mathrm{~K}$ Saro-Wiwa, A Month and a Day, p 81.

${ }^{8}$ K Saro-Wiwa, letter to William Benson, 17 July 1995.

${ }^{9} \mathrm{~K}$ Saro-Wiwa, 'Closing statement to the military appointed tribunal', available at www.mosopcanada.org/ KenStatement.html.

${ }^{10}$ W Soyinka, The Man Died: Prison Notes of Wole Soyinka, Harmondsworth: Penguin, 1979 , p 57.

${ }^{11}$ K Saro-Wiwa, A Month and a Day, p 76.

12 This can clearly be seen in Ken Saro-Wiwa's 15 October 1994 letter to the Ijaw National Congress, which is reproduced in The Ogoni Review, 1(17), 1998, p 1.

${ }^{13}$ M Crow, The Ogoni Crisis: A Case-Study of Military Repression in Southeastern Nigeria, New York: Human Rights Watch, July 1995, p 12.

${ }^{14}$ D Robinson, Ogoni; The Struggle Continues, p 59.

15 J G Frynas, 'Political instability and business: focus on Shell and Nigeria', Third World Quarterly, 19(3), 1998, pp 457-487.

${ }^{16}$ B Manby, 'The role and responsibility of oil multinationals in Nigeria', Journal of International Affairs, 53(1), 1999, pp 281-301.

${ }^{17}$ S Pegg, 'The cost of doing business: transnational corporations and violence in Nigeria', Security Dialogue 30(4), 1999, pp 473-484. 